\title{
Central Amygdala Somatostatin Neurons Gate Passive and Active Defensive Behaviors
}

\author{
Kai Yu, ${ }^{1}$ Pedro Garcia da Silva, ${ }^{1,2}$ Dinu F. Albeanu, ${ }^{1}$ and ${ }^{\circledR B} \mathrm{Bo} \mathrm{Li}^{1}$ \\ ${ }^{1}$ Cold Spring Harbor Laboratory, Cold Spring Harbor, New York 11724, and ${ }^{2}$ Champalimaud Neuroscience Program, Champalimaud Centre for the \\ Unknown, Lisbon 1400-038, Portugal
}

The central amygdala (CeA) has a key role in learning and expression of defensive responses. Recent studies indicate that somatostatinexpressing $\left(\mathrm{SOM}^{+}\right)$neurons in the lateral division of the $\mathrm{CeA}(\mathrm{CeL})$ are essential for the acquisition and recall of conditioned freezing behavior, which has been used as an index of defensive response in laboratory animals during Pavlovian fear conditioning. However, how exactly these neurons participate in fear conditioning and whether they contribute to the generation of defensive responses other than freezing remain unknown. Here, using fiber-optic photometry combined with optogenetic and molecular techniques in behaving mice, we show that $\mathrm{SOM}^{+}$CeL neurons are activated by threat-predicting sensory cues after fear conditioning and that activation of these neurons suppresses ongoing actions and converts an active defensive behavior to a passive response. Furthermore, inhibition of these neurons using optogenetic or molecular methods promotes active defensive behaviors. Our results provide the first in vivo evidence that $\mathrm{SOM}^{+}$neurons represent a CeL population that acquires learning-dependent sensory responsiveness during fear conditioning and furthermore reveal an important role of these neurons in gating passive versus active defensive behaviors in animals confronted with threat.

Key words: active avoidance; central amygdala; fear; fiber-optic photometry; optogenetics; somatostatin neurons

\section{Significance Statement}

The ability to develop adaptive behavioral responses to threat is fundamental for survival. Recent studies indicate that the central lateral amygdala $(\mathrm{CeL})$, in particular its somatostatin-expressing neurons, is crucial for both learning and the expression of defensive response. However, how exactly these neurons participate in such processes remains unclear. Here we show for the first time in behaving mice that the somatostatin-expressing neurons in the CeL acquire learning-dependent responsiveness to sensory cues predicting a threat. Furthermore, our results indicate that these neurons gate the behavioral output of an animal: whereas high activity in these neurons biases toward passive defensive responses, low activity in these neurons allows the expression of active defensive responses.

\section{Introduction}

In the face of threat, animals typically show passive reactions such as freezing or suppression of ongoing activity or active defensive behaviors such as flight or fight (Bouton and Bolles, 1980; Blanchard et al., 2001). The ability to select an appropriate action

\footnotetext{
Received Dec. 10, 2015; revised May 10, 2016; accepted May 11, 2016.

Author contributions: K.Y. and B.L. designed research; K.Y. performed research; P.G.D.S. and D.F.A. contributed unpublished reagents/analytic tools; K.Y. analyzed data; B.L. wrote the paper.

This work was supported by the National Institutes of Health (B.L. and D.F.A.), the National Alliance for Research in Schizophrenia and Affective Disorder (B.L.), the Wodecroft Foundation (B.L.), the Stanley Family Foundation (B.L.), the Simons Foundation Autism Research Initiative (B.L.), and the Fundação para a Ciência e Tecnologia (P.G.D.S.). We thank P. Wulff (University of Kiel, Germany) and W. Wei (University of Chicago) for the AAV.CAG.Flex.TeLC-eGFP plasmid and virus, respectively, Ga-Ram Hwang for technical support, and members of the Li laboratory for discussions.

The authors declare no competing financial interests.

Correspondence should be addressed to Bo Li, PhD, Cold Spring Harbor Laboratory, 1 Bungtown Road, Cold Spring Harbor, NY 11724. E-mail: bli@cshl.edu.

DOI:10.1523/JNEUROSCI.4419-15.2016

Copyright $\odot 2016$ the authors $\quad 0270-6474 / 16 / 366488-09 \$ 15.00 / 0$
}

in such situations is essential for survival. Freezing behavior and suppression of ongoing activity are commonly measured as indices of fear in Pavlovian fear conditioning (LeDoux et al., 1988; Killcross et al., 1997; Amorapanth et al., 1999; Johansen et al., 2011). Extensive studies based on these measurements have established the amygdala, including its basolateral (BLA) and central (CeA) nuclei, as the centerpiece of fear regulation circuits (LeDoux et al., 1988; Duvarci and Pare, 2014; Herry and Johansen, 2014). In particular, the BLA is known as the amygdala nucleus where inputs of different modalities converge and is thought to be critical for the formation of associations between conditioned stimulus (CS) and unconditioned stimulus (US), and thus the formation of memory, during conditioning (for recent reviews, see Duvarci and Pare, 2014; Herry and Johansen, 2014; Gründemann and Lüthi, 2015).

Recent studies indicate that a major cell population in the lateral division of the $\mathrm{CeA}(\mathrm{CeL})$, the somatostatin-expressing $\left(\mathrm{SOM}^{+}\right)$neurons, is essential for both the acquisition and the 
recall of aversive memories, which are measured as the expression of conditioned freezing (Li et al., 2013; Penzo et al., 2014; Penzo et al., 2015). In general, neurons involved in the formation, storage, or recall of memories, such as those in the BLA, should represent the memory-associated sensory cues (Quirk et al., 1995). However, whether $\mathrm{SOM}^{+} \mathrm{CeL}$ neurons have such capacity is unknown because, to date, their activity has not been recorded in vivo in behaving animals. In addition, the role of these neurons in defensive responses other than freezing has yet to be examined. The present study was devised to address these questions.

\section{Materials and Methods}

Animals

Before surgery, mice were group housed under a $12 \mathrm{~h}$ light/dark cycle (7:00 A.M. to 7:00 P.M. light) with food and water available ad libitum. Animals with optical fiber implants were housed singly. The Som-cre (Taniguchi et al., 2011; Li et al., 2013), Ai14 (Madisen et al., 2010), Ai35 (Madisen et al., 2012), and Ai32 (Madisen et al., 2012) mice were described previously and were purchased from the The Jackson Laboratory. All mice were bred onto C57BL/6J genetic background. The Som-cre; Ail4 mice, which were heterozygous for both the Cre allele and the Lox-Stop-Lox-tdTomato allele, were bred by crossing homozygous Somcre mice with homozygous Ail4 reporter mice. The Som-cre;Ai35 mice, which were heterozygous for both the Cre allele and the Lox-Stop-LoxArch-GFP allele, were bred by crossing homozygous Som-cre mice with homozygous Ai35 mice. The Som-cre;Ai32 mice, which were heterozygous for both the Cre allele and the Lox-Stop-Lox-ChR2-EYFP allele, were bred by crossing homozygous Som-cre mice with homozygous Ai32 mice. Male and female mice $40-60 \mathrm{~d}$ of age were used for all experiments. All behavioral experiments were performed during the first $4 \mathrm{~h}$ of the dark cycle. All procedures involving animals were approved by the Institute Animal Care and Use Committees of Cold Spring Harbor Laboratory and were performed in accordance with National Institutes of Health standards.

\section{Stereotaxic surgery}

The AAV1.Syn.Flex.GCaMP6f.WPRE.SV40 and AAV9.EF1a.DIO.eYFP. WPRE.hGH viruses, which express GCaMP6f and eYFP, respectively, in a Cre-dependent manner, were purchased from Penn Vector Core (Philadelphia, PA). The AAV2.CAG.Flex.TeLC-eGFP.WPRE.bGH virus, which expresses TeLC in a Cre-dependent manner, was custom made by the vector core at the University of North Carolina.

Standard surgical procedures were followed for stereotaxic injection (Li et al., 2013; Penzo et al., 2015). Briefly, mice were anesthetized with ketamine (100 mg per kg of body weight) supplemented with dexmedetomidine hydrochloride $(0.4 \mathrm{mg}$ per $\mathrm{kg})$ and positioned in a stereotaxic injection frame (NeuroLab). A digital mouse brain atlas was linked to the injection frame to guide the identification and targeting (Angle Two Stereotaxic System; NeuroLab).

Viruses $(\sim 0.3 \mu \mathrm{l})$ were delivered with a glass micropipette (tip diameter, $\sim 5 \mu \mathrm{m})$ through a skull window $\left(1-2 \mathrm{~mm}^{2}\right)$ by pressure applications (5-20 psi, 5-20 ms at $0.5 \mathrm{~Hz}$ ) controlled by a Picrospritzer III (General Valve) and a pulse generator (Agilent). The injection was performed using the following stereotaxic coordinates for CeL: $-1.22 \mathrm{~mm}$ from bregma, $2.9 \mathrm{~mm}$ lateral from the midline, and $4.6 \mathrm{~mm}$ vertical from pial surface. For the in vivo imaging experiments, immediately after viral injection, an optical fiber (core diameter, $105 \mu \mathrm{m}$, FG105UCA, Thorlabs) was implanted $300 \mu \mathrm{m}$ above the center of injection. The optical fiber, together with the ferrule (Thorlabs), was secured to the skull with C\&B Metabond Quick adhesive luting cement (Parkell), followed by dental cement (Lang Dental Manufacturing).

For the in vivo photostimulation experiments, Som-Cre;Ai32 or Som$\mathrm{Cre} ; \mathrm{H} 2 \mathrm{~B}$ (as the control) mice were bilaterally implanted with optical fibers that were placed above CeL (coordinates of the fiber tip: $-1.22 \mathrm{~mm}$ from bregma, $2.9 \mathrm{~mm}$ lateral from the midline, and $4.3 \mathrm{~mm}$ vertical from pial surface).

Following the above procedures, a small piece of metal bar was mounted on the skull, which was used to hold the mouse in the head fixation frame during experiments.

\section{Behavioral tasks}

Licking behavior. Water deprivation started $23 \mathrm{~h}$ before training. Mice were trained in the head fixation frame for $30 \mathrm{~min}$ on the first day and for 10 min daily in the following days. A metal spout was placed in front of the animal's mouth for water delivery. The spout also served as part of a custom "lickometer" circuit, which registered a lick event each time a mouse completed the circuit by licking the spout while standing on a metal floor. The lick events were recorded by a computer through a custom software written in LabView (National Instruments). Each lick triggered a single opening of a water valve calibrated to deliver $0.3 \mu \mathrm{l}$ of water.

It took mice 4-7 d to achieve stable licking, the criterion for which was $10 \mathrm{~min}$ of continuous licking without any gap longer than $10 \mathrm{~s}$.

Fear conditioning. Mice with stable licking behavior were first subjected to sound habituation sessions ( 1 session/d for $2 \mathrm{~d}$ ), during which an auditory stimulus was presented through a computer speaker in each trial. Each stimulus was composed of 5 pips of pure tone $(8 \mathrm{kHz}, 70 \mathrm{~dB})$. Pip duration was $250 \mathrm{~ms}$ and the inter-pip interval was $750 \mathrm{~ms}$. Each habituation session contained 10 trials with variable intertrial intervals (45-75 s). After habituation, mice were conditioned by pairing the auditory stimulus (CS) with a tail shock (US; $100 \mu \mathrm{A}$ for $500 \mathrm{~ms}$ ), which was generated from an isolator (ISO-Flex; A.M.P. Instruments) and delivered through a pair of wires secured to the tail with silicone tubing. A probabilistic reinforcement schedule (Erlich et al., 2012) was used, in which mice were exposed to 1 session of 10 trials daily for 4 consecutive days and in which the CS was paired with the US in only $30 \%$ of trials. An advantage of this reinforcement schedule is that it leads to the formation of fear memories resistant to extinction, which can potentially affect imaging experiments requiring repeated presentations of CS to conditioned mice.

We used a lick suppression index to quantify animals' performance in this task. The lick suppression index was calculated as follows: lick suppression index $=\left(L_{\mathrm{PRE}}-L_{\mathrm{CS}}\right) /\left(L_{\mathrm{PRE}}+L_{\mathrm{CS}}\right)$, where $L_{\mathrm{PRE}}$ is the number of licks in the $5 \mathrm{~s}$ period before CS onset and $L_{\mathrm{CS}}$ is the number of licks in the 5 s CS period (Erlich et al., 2012).

\section{In vivo fiber-optic photometry}

The custom fiber-optic photometry system used a diode laser $(\lambda=473$ $\mathrm{nm}$; OEM Laser Systems) that was first passed through a band-pass filter (ET480/20x; Chroma Technology), subsequently reflected off of a dichroic mirror (FF495; Semrock), and finally routed into a patch cord (MFP_100/125/900-0.22_1m_FC-ZF1.25; Doric Lenses) using an objective lens $(40 \times, 0.8$ numerical aperture; Olympus) placed under the dichroic mirror. The objective was under filled to achieve a long point spread function. The patch cord had a glass core connected to the implanted optical fiber with the same diameter (106 $\mu \mathrm{m}$; Doric Lenses). The laser intensity was $\sim 16 \mu \mathrm{W}\left(\sim 1 \mathrm{~mW} / \mathrm{mm}^{2}\right.$, constant across trials in the same session) measured at the end of the patch cord. The laser beam was gated by a shutter (Uniblitz Electronic) or an acoustic optic modulator (MTS110-A3-VIS; AA Opto-Electronic) placed in the light path. To reduce photo bleaching, laser illumination started 3 or $4 \mathrm{~s}$ before CS onset and ended $5 \mathrm{~s}$ after CS offset.

GCaMP6f fluorescence was routed and collected by the same optical fiber and objective and then passed through the dichroic mirror followed by a long-pass filter (510LP; Chroma Technology), and subsequently fed onto a photomultiplier tube (PMT) (R9110; Hamamatsu) by a focusing lens. Photo currents were amplified using a $700 \mathrm{MHz}$ pulse amplifier (ZPUL-30P; MiniCircuits), the output of which was digitized through a comparator (PRL-350TTL; Pulse Research Lab) (Driscoll et al., 2011). The threshold for the comparator was calibrated slightly above the dark current elicited by the PMT. Its output was acquired through a $100 \mathrm{MHz}$ counter (PCIe6321; National Instruments), further queried at $1 \mathrm{KHz}$ rate, returning binned photon counts using custom software written in LabView (National Instruments). To correct for slow baseline drifting caused by photobleaching, a time-dependent baseline $F_{0}(t)$ was computed as described previously (Jia et al., 2011). The percentage $\Delta F / F$ was calculated as $100 \times\left(F(t)-F_{0}(t)\right) / F_{0}(t)$, where $F(t)$ is the raw fluorescence signal at time $t$. Average $\Delta F / F$ values during the pre-CS ( $2 \mathrm{~s})$ and CS $(5 \mathrm{~s})$ periods in each trial were used for statistical analysis. 
A

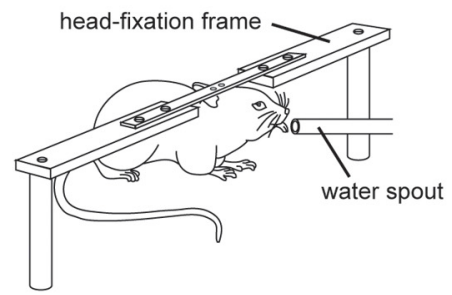

B

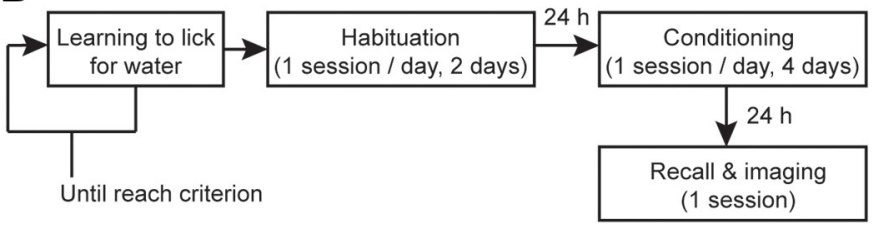

C

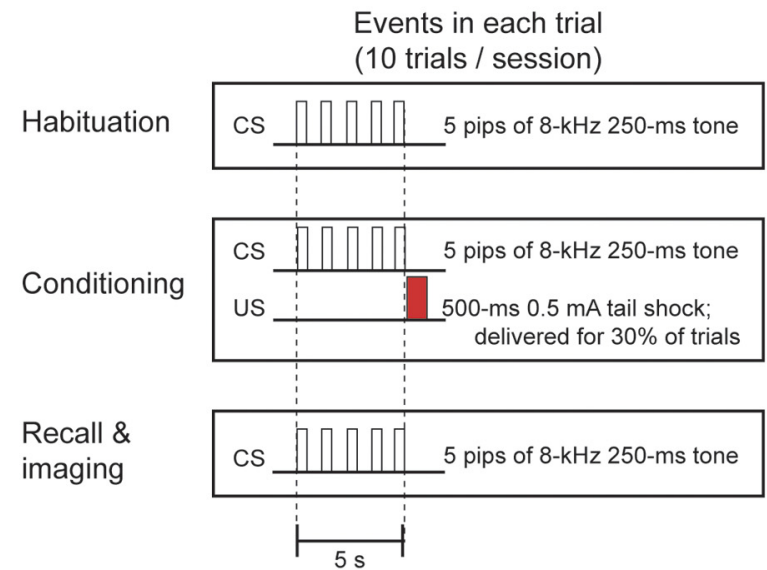

D
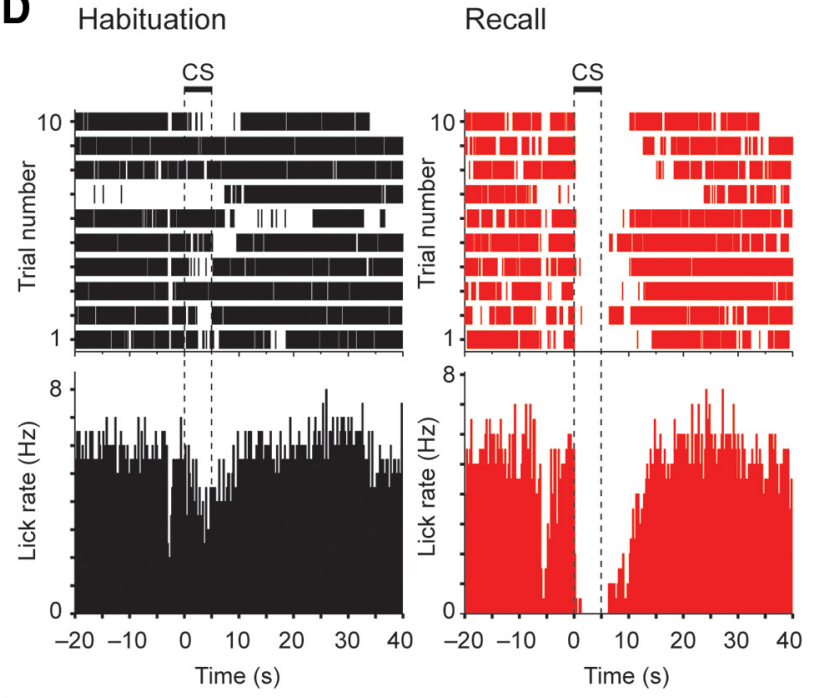

E

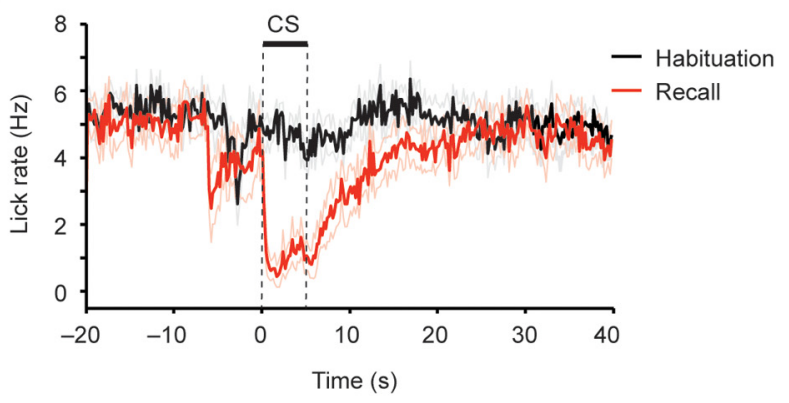

Figure 1. The conditioned lick suppression task. $A$, Schematic of the experimental configuration. $B$, Schematic of the behavioral procedure. $\boldsymbol{C}$, Schematic of events in each trial at each stage of the behavioral procedure. $\boldsymbol{D}$, Quantification of the effect of $C S$ presentations on licking behavior for a representative mouse during habituation (left) and fear memory recall (right). Both the raster plot (top panels) and the peristimulus time histogram (PSTH; bottom panels) of licking activity are shown. $\boldsymbol{E}$, Same as $\boldsymbol{D}$, except average data from 8 mice are shown (habituation, baseline vs $\left(S: t_{(7)}=\right.$ $1.57, p=0.16$, paired $t$ test; recall, baseline vs $\left(S: t_{(7)}=7.69, p=1.17 \mathrm{E}-4\right.$, paired $t$ test; habituation vs recall during $\left(S: t_{(7)}=6.69, p=2.81 \mathrm{E}-4\right.$, paired $t$ test). Note that the transient decrease in lick activity preceding $C S$ presentation was a startle response caused by the noise associated with shutter opening (to turn on the laser for imaging). Data are represented as mean \pm SEM and the shaded lines indicate SEM.

In vivo optogenetics

For bilateral optogenetic stimulation in the CeL, a branched patch-cord (BFP(2)_105/125/900-0.22_1m_FC-2xZF1.25; Doric Lenses) for light delivery was connected at one end to a laser source $(\lambda=473 \mathrm{~nm}$; OEM Laser Systems) and, at the other end, which was composed of two terminals, to two CeL-implanted optical fibers through sleeves (Thorlabs). For photostimulation-induced lick suppression, the stimuli were $5 \mathrm{~ms} 30 \mathrm{~Hz}$ light pulses delivered for $10 \mathrm{~s}$. For photostimulation during active avoidance task, $5 \mathrm{~ms} 30 \mathrm{~Hz}$ light pulses were delivered $1 \mathrm{~s}$ before and coterminated with a $6 \mathrm{~s}$ CS (sound). Laser intensity was $10 \mathrm{~mW}$ measured at the end of optical fiber.

\section{Active avoidance task}

Mice were habituated on a custom running wheel under the head fixation frame for $1 \mathrm{~h}$ the day before training. The running wheel (diameter, 14 $\mathrm{cm}$; width $8 \mathrm{~cm}$ ) was made using a 3D printer (MakerBot Replicator 2; MakerBot). A rotary encoder (YUMO-E6B2-CWZ3E-1024; SparkFun Electronics) was attached to the wheel and connected with a microcontroller (Arduino UNO R3; SparkFun Electronics). The microcontroller converted the digital inputs from the rotary encoder into analog signals reflecting movement velocity, which was in turn recorded by custom software written in Labview (National Instruments).

During training, a CS consisting of 6 pips of $500 \mathrm{~ms}$ white noise was presented, indicating that an air puff to the face would be delivered in $1.5 \mathrm{~s}$. The air puff could be prevented or aborted if mice ran in response to the $\mathrm{CS}$ and reached a threshold speed $(5 \mathrm{~cm} / \mathrm{s})$. Mice were trained daily for one session of 300 trials. Once mice reached $75 \%$ performance (calculated as the percentage of successful avoidance trials), they were sub- jected to a testing session the following day. During testing, mice were exposed to 200 trials of CS presentations, 50\% of which (randomly distributed) were delivered together with photostimulation in the CeL. Running speed and time stamps for CS presentations were recorded.

\section{Statistics and data presentation}

All data are presented as mean \pm SEM. All statistics are indicated where used. Data were analyzed with Origin 8 Software (OriginLab). Normality was tested by D'Agostino-Pearson or Shapiro-Wilk normality test. Behavioral tests and imaging data acquisition were performed by an investigator with knowledge of the identity of the experimental groups. All behavior experiments were controlled by computer systems and data were collected and analyzed in an automated and unbiased way. No single data points were excluded. Virus-injected animals in which the injection site was incorrect were excluded.

\section{Results}

To investigate how $\mathrm{SOM}^{+} \mathrm{CeL}$ neurons contribute to the generation of defensive behaviors, we set out to monitor the activity of these neurons in vivo in mice performing a conditioned lick suppression task (Erlich et al., 2012) in which a CS predicting a noxious US suppresses licking for water in water-deprived mice (Fig. 1A-E). Mice in this task had stable and high baseline lick rate (Fig. $1 D, E$ ). After conditioning by pairing the CS (pips of sound) with the US (tail shocks) (Fig. $1 A-C$ ), sound presentation alone caused marked reduction in lick rate, indicating the formation of CS-US association (Fig. 1D,E). 
A

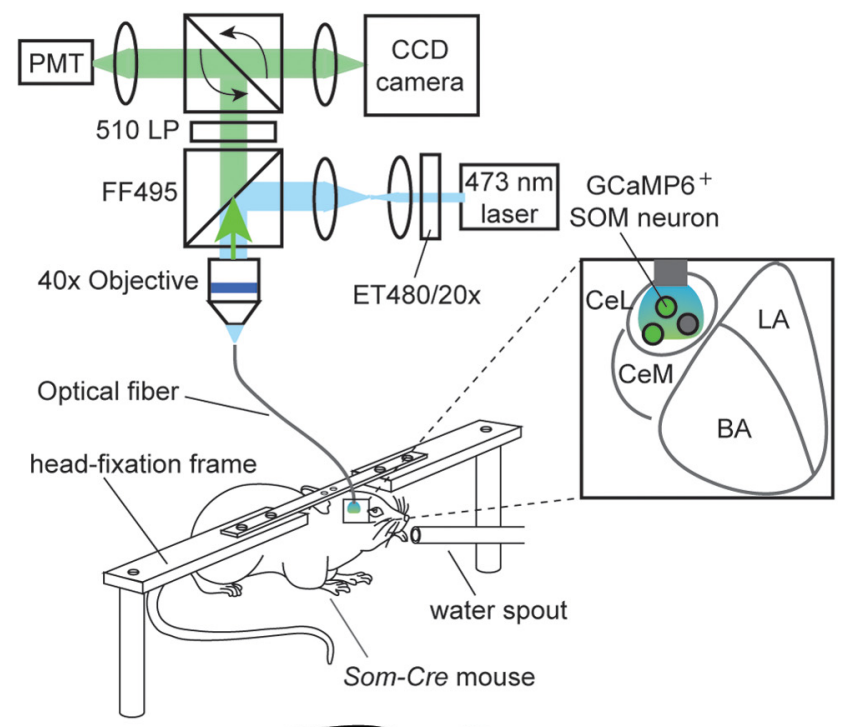

D

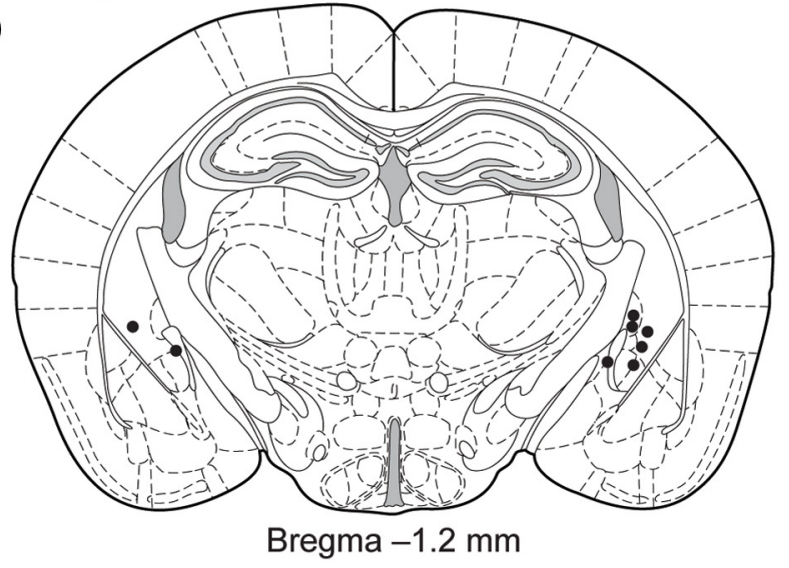

E

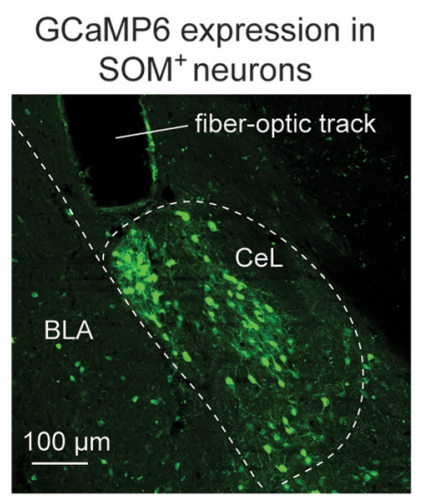

$\mathbf{F}$

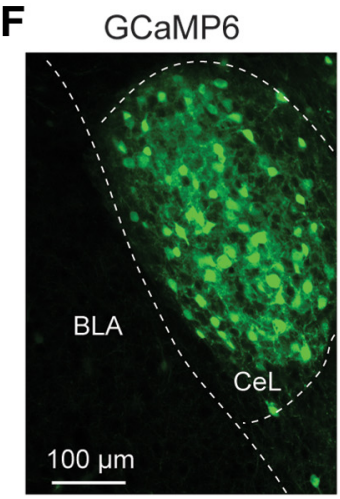

B
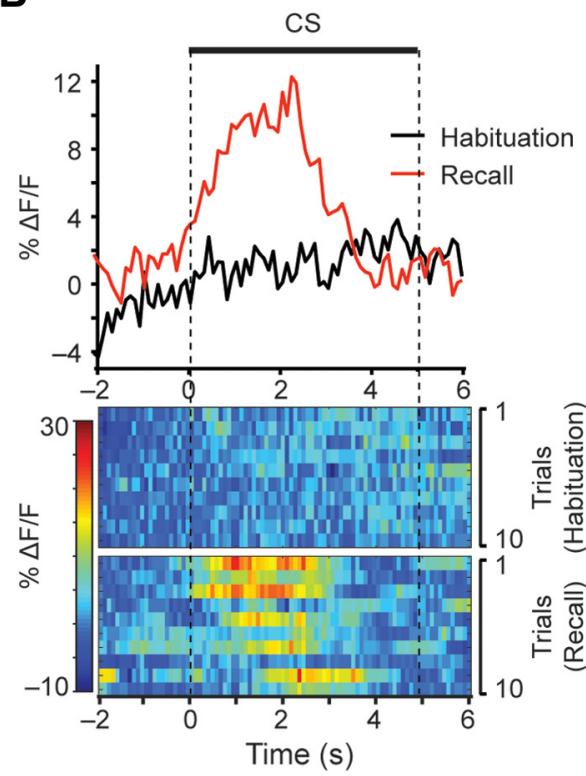

C - Habituation

- Recall

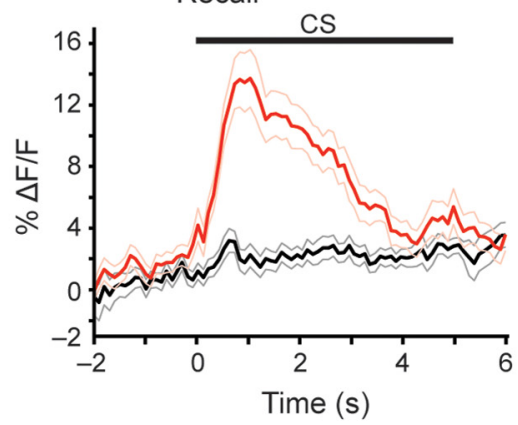

tdTomato
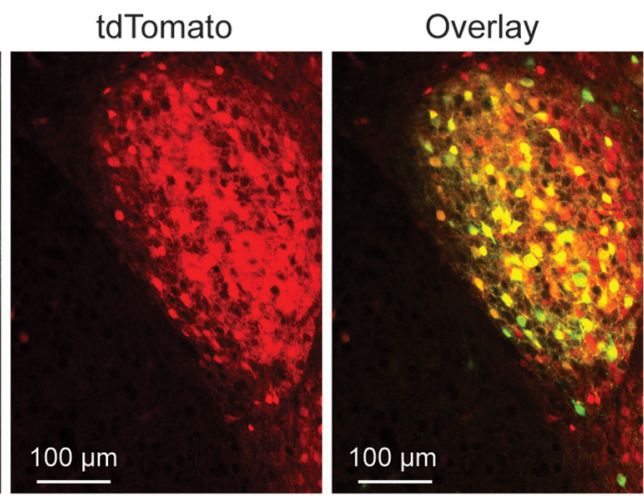

Figure 2. Imaging the activity of SOM ${ }^{+}$CeL neurons during fear conditioning. A, Schematic of the experimental configuration. B, Quantification of GCaMP6 f fluorescence signals recorded from $\mathrm{SOM}^{+}$CeL neurons in a representative mouse, showing average (top) and trial-by-trial (bottom) $\Delta F / F$ over time. C, Average GCaMP6f fluorescence signals from 8 mice (habituation, baseline vs CS: $t_{(79)}=-2.7, p=0.01$, paired $t$ test; recall, baseline vs $\left(S: t_{(79)}=-7.74, p=2.81 \mathrm{E}-11\right.$, paired $t$ test; habituation vs recall during $\left(S: t_{(158)}=-6.47, p=1.17 \mathrm{E}-9, t\right.$ test). Data are represented as mean \pm SEM and the shaded lines indicate SEM. D, Drawing of optical fiber placement. Each black dot denotes where the tip of the optical fiber was located in each mouse $(n=8)$. $\boldsymbol{E}$, Histology showing expression of GCaMP6f in SOM ${ }^{+}$CeL neurons in the representative mouse in $\boldsymbol{B}$. $\boldsymbol{F}$, Images of a brain section from a Som-Cre;Air4 mouse in which the CeL was injected with the AAV.Flex.GCaMP6f. The expression of GCaMP6f (left) in CeL neurons was detected based on its intrinsic fluorescent signal (green). SOM $^{+}$neurons (red) were identified based on their expression of tdTomato (middle). The GCaMP6f was predominately ( $>96 \%$ ) expressed in SOM ${ }^{+}$neurons (right).

To enable selective recording of $\mathrm{SOM}^{+} \mathrm{CeL}$ neuron activity, we used Som-Cre mice, in which expression of the Cre recombinase is driven by the endogenous SOM promoter (Taniguchi et al., 2011), in the conditioned lick suppression task. In addition, before the behavioral training, we injected the CeL of these mice with an adeno-associated virus (AAV) expressing GCaMP6f, the genetically encoded $\mathrm{Ca}^{2+}$ indicator (Chen et al., 2013), in a Credependent manner (AAV.Flex.GCaMP6f; Fig. $2 A-F$ ), followed by implanting an optical fiber above the CeL (Fig. $2 A, D$ ). The GCaMP6f signals from SOM ${ }^{+}$CeL neurons in these mice during 
A
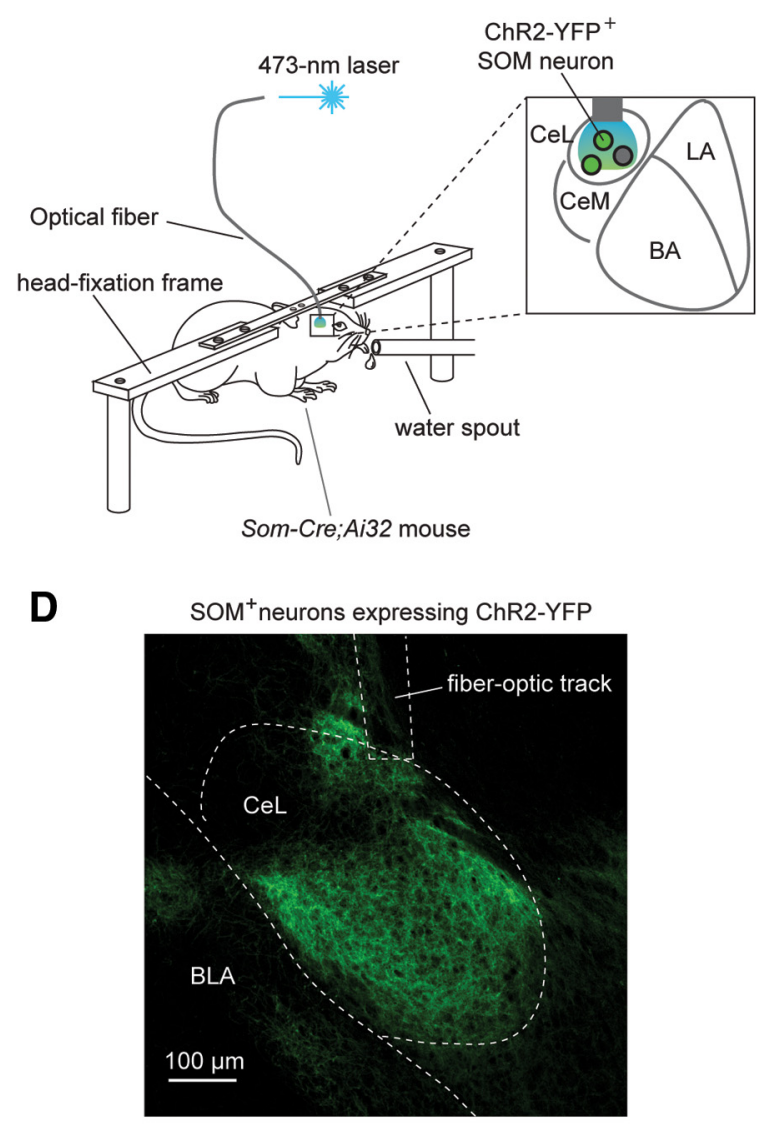

E

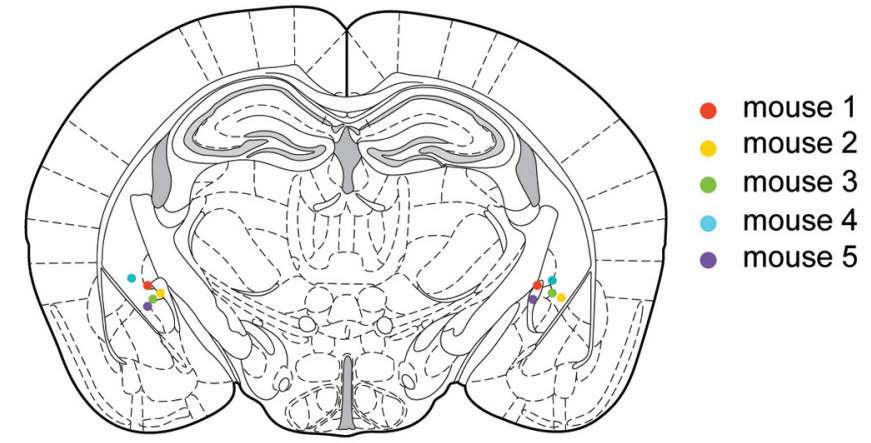

$\mathbf{B}$

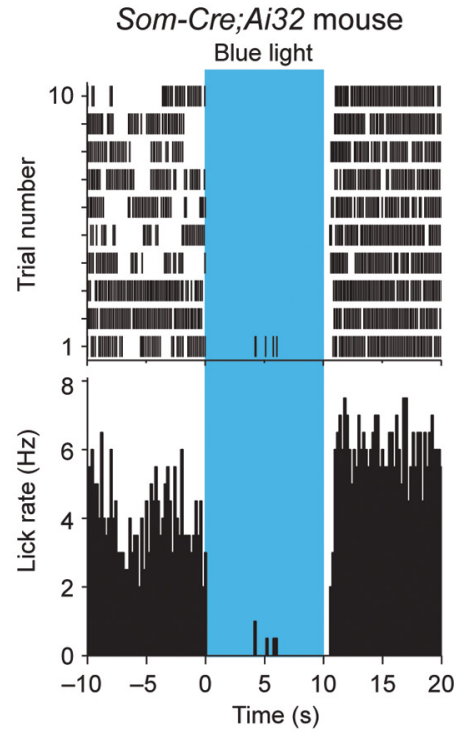

C

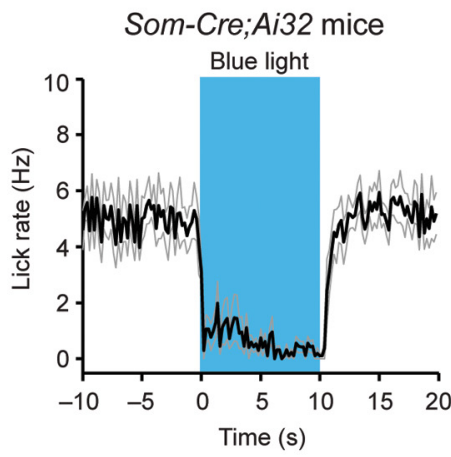

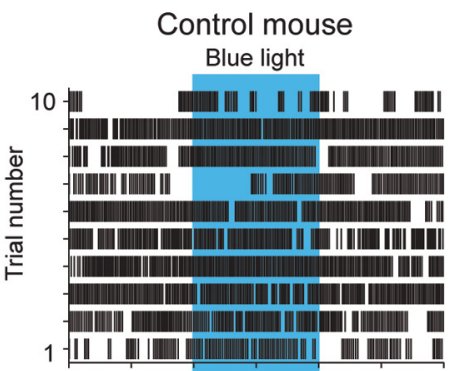

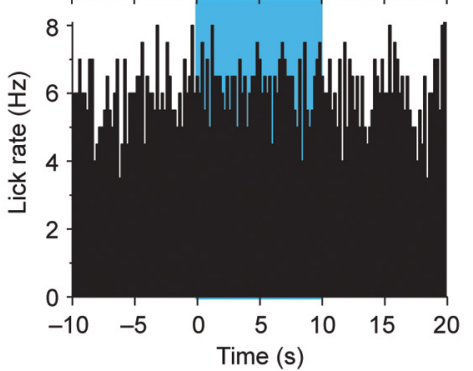

Control mice

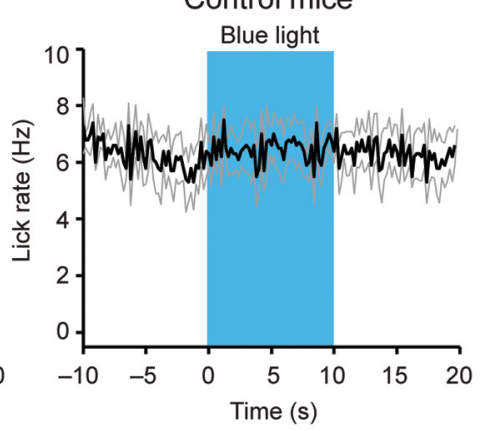

Bregma $-1.2 \mathrm{~mm}$

Figure 3. Optogenetic activation of $\mathrm{SOM}^{+} \mathrm{CeL}$ neurons instantaneously suppresses licking behavior. $\boldsymbol{A}$, Schematic of the experimental configuration. $\boldsymbol{B}$, Quantification of the effect of photostimulation on licking behavior for two mice in which either ChR2 (left) or eYFP (right) was expressed in SOM ${ }^{+}$CeL neurons. Both raster plot (top) and peristimulus time histogram (PSTH; bottom) of licking activity are shown. $\boldsymbol{C}$, Same as $\boldsymbol{B}$ except average data from 5 mice for each group are shown (Som-Cre;Ai32 mice, baseline vs phostostimulation: $t_{(4)}=9.13, p=7.99 \mathrm{E}-4 ;$ control mice, baseline vs phostostimulation: $t_{(4)}=-1.26, p=0.27$; paired $t$ test). Data are represented as mean \pm SEM and the shaded lines indicate SEM. $\boldsymbol{D}$, Histology result from a representative Som-Cre;Ai32 mouse. $\boldsymbol{E}$, Drawing of optical fiber placement in the Som-Cre;Ai32 mice. Each pair of dots of the same color denotes bilateral placement of the tips of the optical fibers in one mouse $(n=5)$.

the lick suppression task could therefore be recorded using a fiber-optic photometry strategy (Cui et al., 2013; Gunaydin et al., 2014; see Materials and Methods; Fig. 2). To facilitate recording and minimize any motion artifacts, experiments were performed in a head-fixation configuration (Fig. 2A).

Notably, in the mice that had been trained in the conditioned lick suppression task, CS presentations not only induced suppression of the licking behavior (Fig. $1 D, E$ ), but also evoked a transient increase in GCaMP6f signals, indicating the activation of SOM ${ }^{+}$CeL neurons (Fig. $2 B, C$ ). In contrast, sound presentation before the conditioning did not elicit lick suppression (Fig. $1 D, E)$ nor did it induce appreciable activation of $\mathrm{SOM}^{+} \mathrm{CeL}$ neurons (Fig. $2 B, C$ ). These results, together with our previous finding that excitatory synaptic transmission from the BLA onto $\mathrm{SOM}^{+}$CeL neurons is potentiated after fear conditioning ( $\mathrm{Li}$ et al., 2013), indicate that $\mathrm{SOM}^{+}$CeL neurons become responsive to the threat-predicting sensory stimulus in a learning-dependent manner.

The population average response dynamics of $\mathrm{SOM}^{+} \mathrm{CeL}$ neurons suggest that they might contribute to the generation of lick suppression. We therefore tested whether activation of $\mathrm{SOM}^{+} \mathrm{CeL}$ neurons is sufficient to drive lick suppression in unconditioned mice. To this end, we implanted optical fibers bilaterally above the CeL of Som-Cre;Ai32 mice (Madisen et al., 2012), 
A

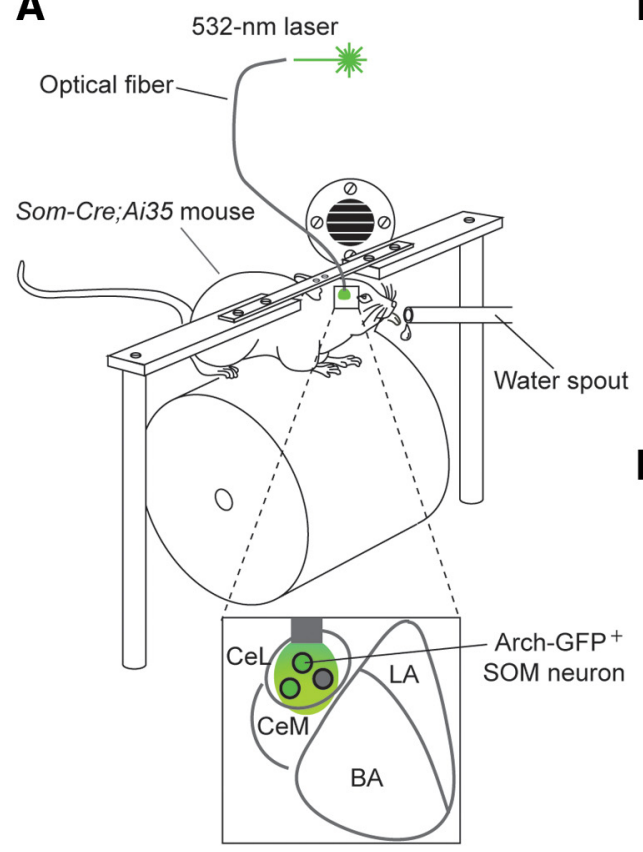

B
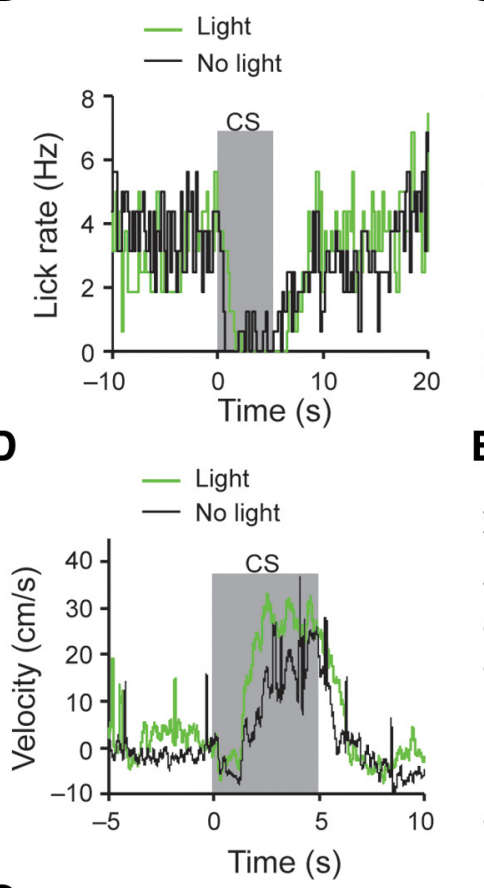

C
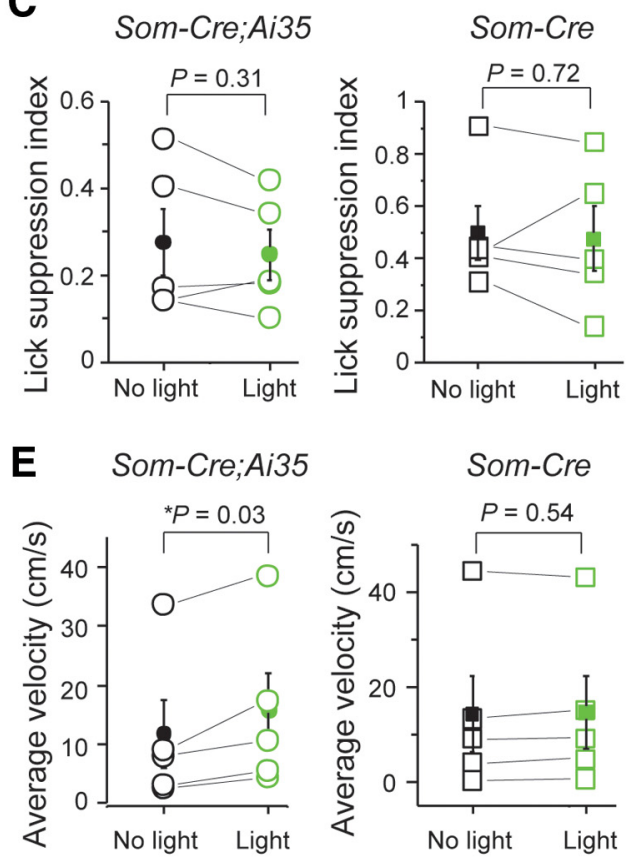

Som-Cre

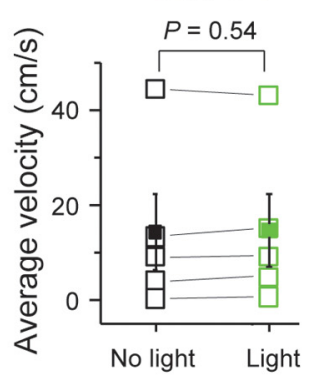

F

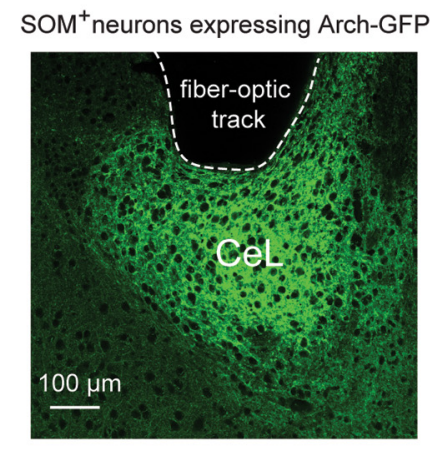

\section{G}

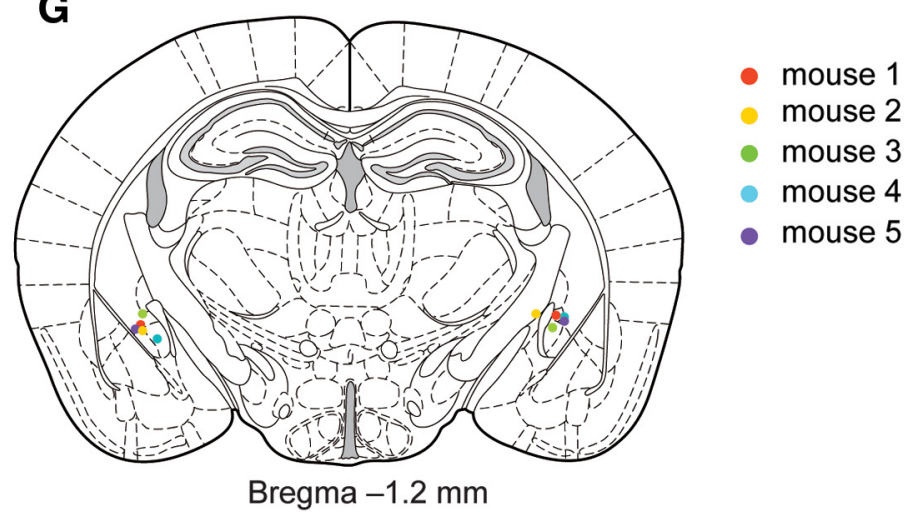

Figure 4. Optogenetic inhibition of $\mathrm{SOM}^{+}$CeL neurons facilitates conditioned running response. $\boldsymbol{A}$, Schematic of the experimental configuration. $\boldsymbol{B}, \boldsymbol{D}, \mathrm{Q}$ uantification of the effects of optogenetic inhibition of $\mathrm{SOM}^{+}$CeL neurons on the simultaneously measured licking $(\boldsymbol{B})$ and running $(\boldsymbol{D})$ behaviors of a representative Som-Cre; $A$ i35 mouse. A continuous green light pulse covering the entire duration of a trial was delivered into the $C$ eL in interleaved trials. The average lick rate $(\boldsymbol{B})$ or running velocity $(\boldsymbol{D})$ for trials with or without light delivery was plotted separately and color coded. $\boldsymbol{C}$, $\boldsymbol{E}$, Quantification of the effects of light delivery into the $(e$ L on the simultaneously measured conditioned lick suppression ( $\boldsymbol{C}$ ) and conditioned running (E) in Som-Cre;Ai35 mice and control Som-Cre mice. Each open circle represents the mean value for one mouse. Each filled circle and its error bars represent the mean \pm SEM of a group of mice. $C$, Quantification of conditioned lick suppression index (see Materials and Methods) for trials with or without light delivery into the CeL of Som-Cre;Ai35 mice (left; no light, $0.27 \pm 0.08$, light, $0.25 \pm 0.06, n=5, t_{(4)}=1.15, p=0.31$, paired $t$ test) and control Som-Cre mice (right; no light, $0.50 \pm 0.10$, light, $0.48 \pm 0.12, n=5, t_{(4)}=0.39, p=0.72$; paired $t$ test). $\boldsymbol{E}$, Quantification of average running velocity during (S presentation for trials with or without light delivery into the CeL of Som-Cre;Ai35 mice (left; no light, $11.74 \pm 5.73$, light, $15.67 \pm 6.27, n=5, t_{(4)}=3.34,{ }^{*} p=0.03$, paired $t$ test) and control Som-Cre mice (right; no light, $14.21 \pm 7.86$, light, $14.55 \pm 7.54, n=5, t_{(4)}=-0.67, p=0.54$; paired $t$ test). $\boldsymbol{F}$, Histology result from a representative Som-Cre;Ai35 mouse. $\mathbf{G}$, Drawing of optical fiber placement in the Som-Cre;Ai35 mice. Each pair of dots of the same color denotes bilateral placement of the tips of the optical fibers in one mouse $(n=5)$.

in which the light-sensitive cation channel channelrhodopsin-2 (ChR2; Zhang et al., 2006) is specifically expressed in $\mathrm{SOM}^{+}$cells (Li et al., 2013; Fig. 3A-E). Once these mice had been trained for licking, we delivered pulses of blue light into the CeL to activate the ChR2-expressing SOM ${ }^{+}$neurons. Remarkably, photostimulation elicited an abrupt and near complete suppression of licking, which was rapidly reversible upon the cessation of light (Fig. $3 B, C)$. Light delivery into the CeL in which $\mathrm{SOM}^{+}$neurons expressed eYFP did not induce lick suppression (Fig. $3 B, C$ ). Therefore, these results demonstrate that $\mathrm{SOM}^{+} \mathrm{CeL}$ neuron activation is sufficient to induce lick suppression, mimicking the effect of presenting a CS that predicts a noxious US.

Could $\mathrm{SOM}^{+} \mathrm{CeL}$ neurons be necessary for lick suppression? To address this question, we inhibited these neurons while ani- mals were performing the conditioned lick suppression task. For this purpose, we implanted optical fibers bilaterally above the CeL of Som-Cre;Ai35 mice (Madisen et al., 2012) in which the light-sensitive proton pump archaerhodopsin (Arch; Chow et al., 2010 ) is expressed specifically in $\mathrm{SOM}^{+}$cells ( $\mathrm{Li}$ et al., 2013; Fig. $4 A-G)$. After training in the conditioned lick suppression task, these mice were tested in a recall session during which continuous green light was delivered into the $\mathrm{CeL}$ in interleaved trials to inhibit the Arch-expressing SOM ${ }^{+}$neurons. To assess whether this manipulation could affect lick suppression as well as other forms of defensive behavior, we allowed the mice to run on a wheel throughout the conditioned lick suppression task (Fig. $4 A$ ). We found that photoinhibition of $\mathrm{SOM}^{+} \mathrm{CeL}$ neurons failed to have an effect on conditioned lick suppression (Fig. 
A

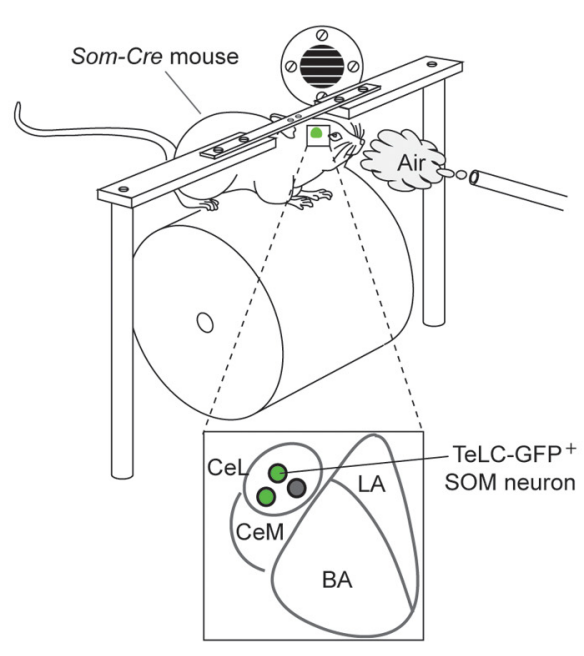

B

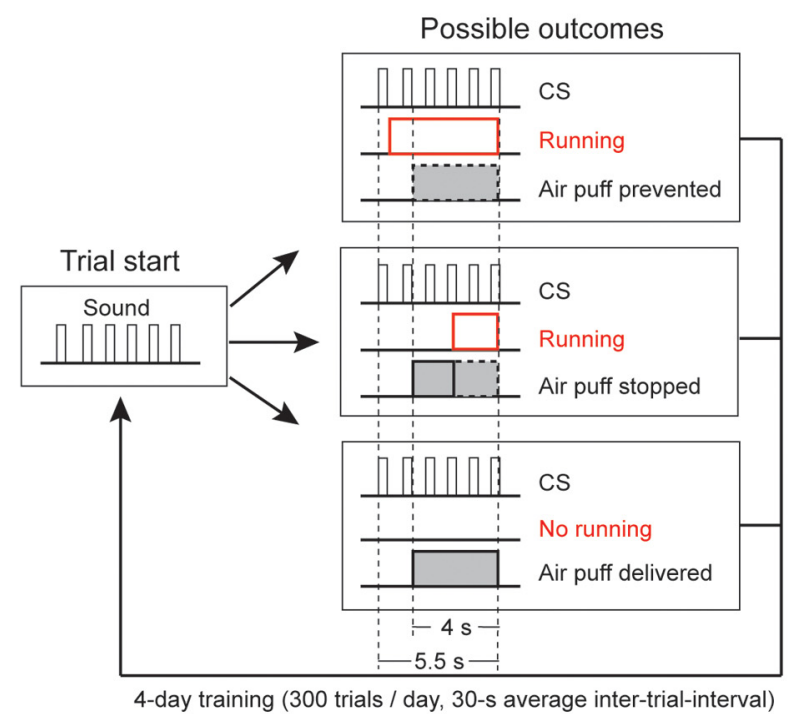

C

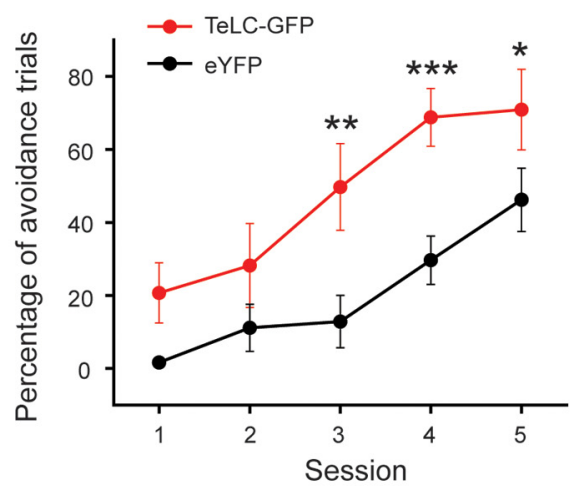

D

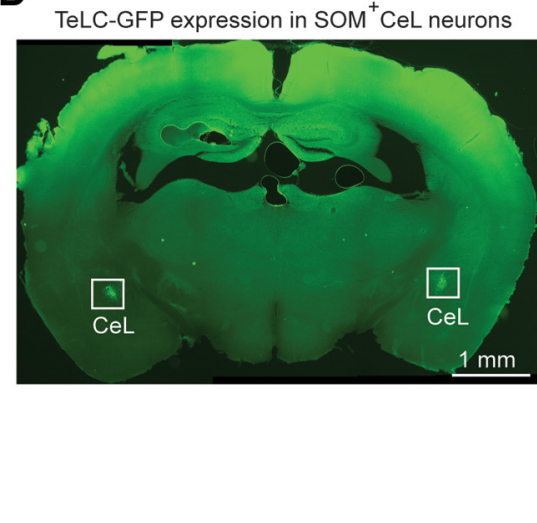

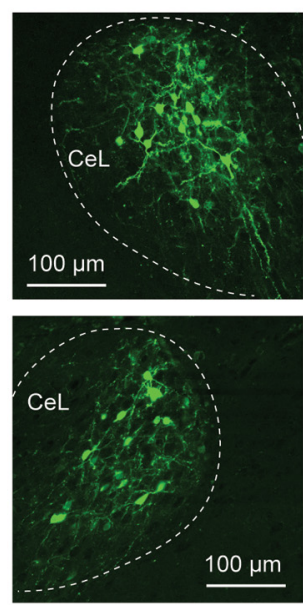

Figure 5. $\mathrm{SOM}^{+}$CeL neurons repress active avoidance. $A$, Schematic of the experimental configuration. $\boldsymbol{B}$, A schematic of the training procedure. $\boldsymbol{C}$, Effects of tetanus toxin light chain (TeLC) inhibition of SOM ${ }^{+}$CeL neurons on active avoidance (TeLC, $n=5$ mice; eYFP, in which SOM ${ }^{+}$CeL neurons expressed eYFP, $n=5$ mice; $F_{(1,8)}=7.72 ; p=0.02$, two-way repeated-measures ANOVA; post hoc Tukey's tests, ${ }^{*} p=0.05,{ }^{* *} p=0.005,{ }^{* * *} p=0.003$ ). (D) Histology result from a representative mouse used in $C$. On the right are high-magnification images of the boxed areas on the left.

$4 B, C)$. Interestingly, these mice showed CS-induced running behavior in addition to lick suppression and this conditioned running was consistently enhanced by photoinhibition of $\mathrm{SOM}^{+}$ CeL neurons (Fig. 4D,E). Light delivery into the CeL of control mice did not affect either lick suppression or running (Fig. 4C,E). Therefore, inhibition of $\mathrm{SOM}^{+}$CeL neurons facilitated CSinduced running, suggesting that the ongoing activity of $\mathrm{SOM}^{+}$ CeL neurons normally may suppress active behaviors. By contrast, the same manipulation did not affect conditioned lick suppression; this could be because that the mice were engaged in a different defensive behavior-running-and thus were not able to lick in response to the CS. These results also imply that the $\mathrm{SOM}^{+}$ CeL neurons may not be essential for the subjective feeling of fear; rather, they may be important for determining the type of defensive responses, passive or active, to be expressed as the behavioral output.

To further investigate whether $\mathrm{SOM}^{+} \mathrm{CeL}$ neurons influence active defensive behaviors, we sought to inhibit these neurons using a potent molecular method because optogenetic inhibition suffers from limited light coverage within the CeL that may lead to underestimation of the behavioral effect. We injected the CeL of Som-Cre mice bilaterally with an AAV expressing the tetanus toxin light chain (TeLC; Murray et al., 2011), which inhibits neuronal output by preventing synaptic vesicle fusion, or GFP (as a control) in a Cre-dependent manner (AAV.Flex.TeLC-eGFP or AAV.DIO.eYFP, respectively; Fig. $5 A$ ). We subsequently trained these mice in an active avoidance task in which a CS (sound) predicted a noxious US (air puff delivered to the face) and running above a set threshold speed would either prevent or terminate the US (Fig. 5A,B). Compared with the eYFP control mice, the TeLC group showed markedly improved performance in this task (Fig. $5 C, D$ ), indicating that the endogenous activity of $\mathrm{SOM}^{+}$CeL neurons acts to repress active defensive behaviors.

Given the observations described above, we reasoned that increasing the activity of $\mathrm{SOM}^{+} \mathrm{CeL}$ neurons might be sufficient to block active defensive responses. To test this hypothesis, we implanted optical fibers bilaterally above the CeL of Som-Cre;Ai32 mice, which were subsequently trained in the active avoidance task (Figs. $6 A, 5 B$ ). Once these mice mastered the task, as evidenced by their ability to reduce the frequency of US delivery effectively by running in response to the CS, they were tested for conditioned avoidance. In interleaved trials, $\mathrm{SOM}^{+} \mathrm{CeL}$ neurons 
A

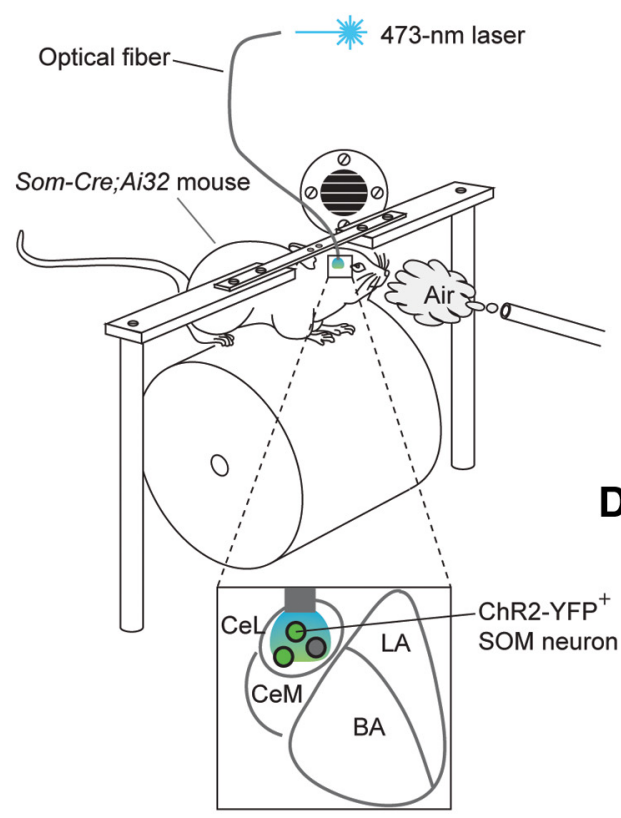

B

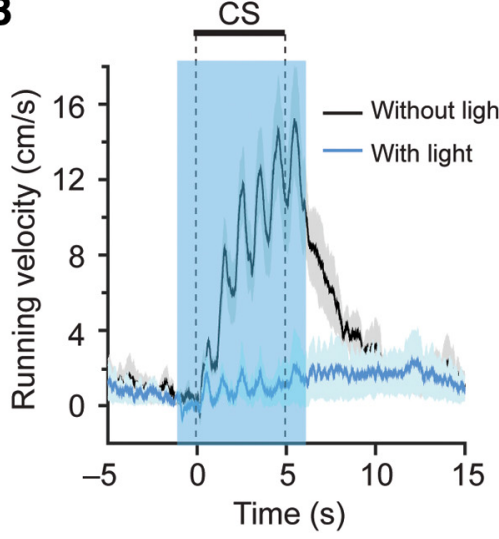

C

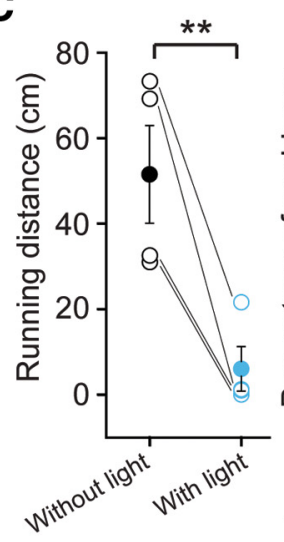

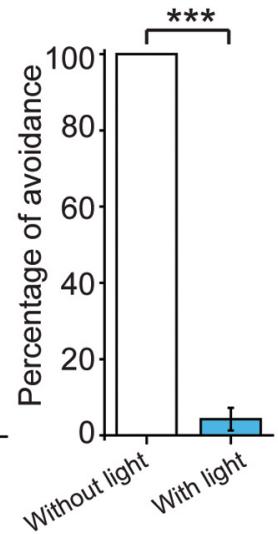

ChR2-YFP expressionin som+

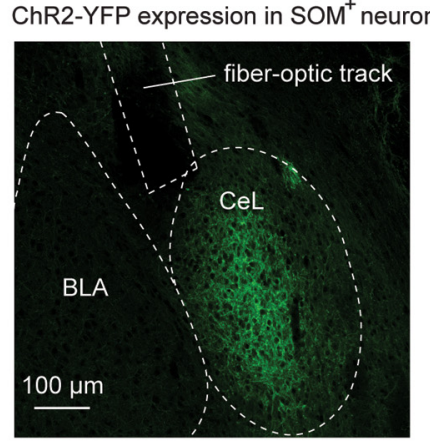

\section{$\mathrm{E}$}

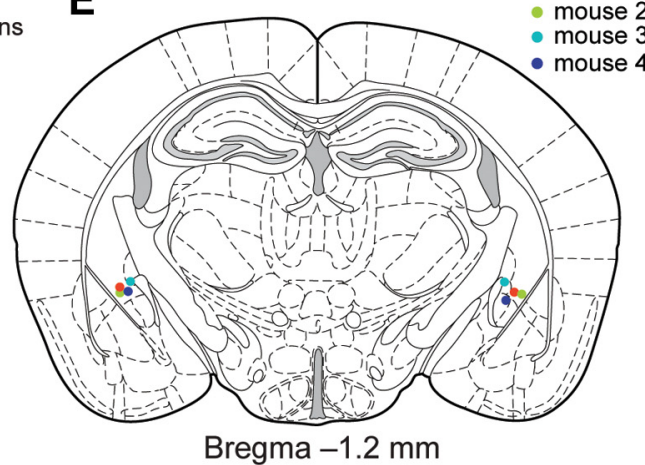

Bregma $-1.2 \mathrm{~mm}$

Figure 6. $\mathrm{SOM}^{+}$CeL neurons inhibits active avoidance. $\boldsymbol{A}$, Schematic of the experimental configuration. $\boldsymbol{B}$, Quantification of the effect of photostimulation on running velocity of a representative mouse (comparing trials that had no photostimulation with trials that had photostimulation; 100 trials for each condition). $C$, Left, Quantification of the effect of photostimulation on running distance (comparing total running distance in response to CS presentations in trials that had no photostimulation with that in trials that had photostimulation; ${ }^{* *} p=0.01, t=5.1$, paired $t$ test,$n=$ 4 mice). Right, Quantification of the effect of photostimulation on avoidance (comparing the percentage of successful avoidance in response to CS presentations in trials that had no photostimulation with that in trials that had photostimulation; ${ }^{* * *} p=6.6 \mathrm{E}-5, t=32.1$, paired $t$ test, $n=4$ mice). $\boldsymbol{D}$, Histology results from a representative mouse. $E$, Drawing of optical fiber placement. Each pair of dots of the same color denotes bilateral placement of the tips of the optical fibers in one mouse $(n=4)$. In $\boldsymbol{B}$ and $\boldsymbol{C}$, data are represented as mean \pm SEM. The shades along the velocity traces in $B$ indicate the SEM.

were photostimulated with light trains that cover the entire duration of the CS (Figs. $6 B, 3$ ). CS presentation triggered robust running behavior in these mice, which was completely abolished by photostimulation of $\mathrm{SOM}^{+} \mathrm{CeL}$ neurons (Fig. $6 B-E$ ). This result indicates that $\mathrm{SOM}^{+} \mathrm{CeL}$ neuron activity is sufficient to convert an active defensive behavior into a passive response.

\section{Discussion}

Recent studies have shown that fear conditioning modifies the response properties of CeL neurons to sensory stimuli. In particular, a population of neurons, the " $\mathrm{CeL}_{\mathrm{ON}}$ " neurons, is activated by the CS in fear-conditioned animals (Ciocchi et al., 2010; Duvarci et al., 2011). However, the identity of these neurons has been unknown. In addition, it is also unclear whether and how the activity of these $\mathrm{CeL}_{\mathrm{ON}}$ neurons is causally related to the generation of defensive behavioral responses.

Our study shows for the first time in behaving animals that $\mathrm{SOM}^{+} \mathrm{CeL}$ neurons are activated by sensory cues predicting an aversive outcome. This result, together with the finding that excitatory synapses onto $\mathrm{SOM}^{+} \mathrm{CeL}$ neurons driven by inputs from the lateral amygdala are potentiated by fear conditioning $(\mathrm{Li}$ et al., 2013), suggests that these neurons represent, at least in part, the previously reported $\mathrm{CeL}_{\mathrm{ON}}$ neurons (Ciocchi et al., 2010; Duvarci et al., 2011).

The temporal resolution of our recording method, fiber-optic photometry, depends on the kinetics of the GCaMP6 signal (on the order of hundreds of milliseconds to seconds; Chen et al.,
2013), which does not allow us to measure the latency at which neurons are activated accurately and thus to determine the precise temporal relationship between $\mathrm{SOM}^{+} \mathrm{CeL}$ neuron activity and behavior. Nevertheless, the response properties of $\mathrm{SOM}^{+}$ CeL neurons revealed by this method, in conjunction with the findings that activation of $\mathrm{SOM}^{+} \mathrm{CeL}$ neurons in unconditioned mice is sufficient to drive defense-like responses, including lick suppression (this study) and freezing (Li et al., 2013), and that inactivation of these neurons during recall blocks freezing in conditioned mice (Li et al., 2013), indicate a causal link between $\mathrm{SOM}^{+} \mathrm{CeL}$ neuron activation and the expression of passive defensive behaviors.

It is important to note that, in the lick suppression task, the experimental sessions were the only time window during which water was available (through lick) to the water-deprived mice. Therefore, our results indicate that $\mathrm{SOM}^{+} \mathrm{CeL}$ neuron activation is sufficient to halt an ongoing activity instantaneously, even when it is essential for survival.

The novel behavioral tasks, in which lick suppression and running can be monitored simultaneously in the same mice (Fig. 4) and in which active avoidance can be readily assessed under head fixation (Figs. 5, 6), allowed us to reveal that $\mathrm{SOM}^{+} \mathrm{CeL}$ neurons do not simply drive freezing, but rather have a broader role in controlling ongoing behavioral actions. Our results suggest that $\mathrm{SOM}^{+} \mathrm{CeL}$ neurons gate the behavioral output of an animal: whereas high activity in these neurons biases toward passive ac- 
tions (such as freezing or lick suppression), low or no activity in these neurons allows the expression of active responses (such as running or active avoidance). We propose that the activity of $\mathrm{SOM}^{+} \mathrm{CeL}$ neurons needs to be adjusted flexibly for the expression of adaptive defensive behaviors. For instance, when a threat is close, these neurons need to be highly active to drive freezing or call a halt to all ongoing behavioral activities; whereas when a threat is distant, these neurons should be suppressed, thereby allowing escape or avoidance (Schiff et al., 1962; Fanselow and Lester, 1988; McNaughton and Corr, 2004).

The results showing that inhibition of $\mathrm{SOM}^{+} \mathrm{CeL}$ neurons does not affect conditioned lick suppression, but rather enhances conditioned running and active avoidance, are particularly interesting, because they suggest that these neurons are likely not essential for producing the negative motivations associated with the US (e.g., the "feeling of fear"). Consistent with this interpretation, although photostimulation of $\mathrm{SOM}^{+} \mathrm{CeL}$ neurons induced robust lick suppression, the recovery of licking, which was almost instantaneous after the cessation of light (Fig. $3 B, C$ ), seems too fast if these neurons had caused any negative motivations (e.g., see the recovery time course of the CS-induced lick suppression in Fig. 1).

The downstream circuitry that mediates the behavioral effects of $\mathrm{SOM}^{+} \mathrm{CeL}$ neurons is currently unknown. These effects could be mediated by the local inhibitory interactions between $\mathrm{SOM}^{+} \mathrm{CeL}$ neurons and other CeL populations, including the corticotropinreleasing hormone-expressing neurons (Day et al., 1999) and the protein kinase C- $\delta$-expressing neurons (Haubensak et al., 2010), or by the long-range interactions of $\mathrm{SOM}^{+} \mathrm{CeL}$ neurons with extraamygdaloid structures, such as the periaqueductal gray or the paraventricular nucleus of the thalamus (Penzo et al., 2014).

\section{References}

Amorapanth P, Nader K, LeDoux JE (1999) Lesions of periaqueductal gray dissociate-conditioned freezing from conditioned suppression behavior in rats. Learn Mem 6:491-499. CrossRef Medline

Blanchard DC, Griebel G, Blanchard RJ (2001) Mouse defensive behaviors: pharmacological and behavioral assays for anxiety and panic. Neurosci Biobehav Rev 25:205-218. CrossRef Medline

Bouton ME, Bolles RC (1980) Conditioned fear assessed by freezing and by the suppression of three different baselines. Animal Learning \& Behavior 8:429-434. CrossRef

Chen TW, Wardill TJ, Sun Y, Pulver SR, Renninger SL, Baohan A, Schreiter ER, Kerr RA, Orger MB, Jayaraman V, Looger LL, Svoboda K, Kim DS (2013) Ultrasensitive fluorescent proteins for imaging neuronal activity. Nature 499:295-300. CrossRef Medline

Chow BY, Han X, Dobry AS, Qian X, Chuong AS, Li M, Henninger MA, Belfort GM, Lin Y, Monahan PE, Boyden ES (2010) High-performance genetically targetable optical neural silencing by light-driven proton pumps. Nature 463:98-102. CrossRef Medline

Ciocchi S, Herry C, Grenier F, Wolff SB, Letzkus JJ, Vlachos I, Ehrlich I, Sprengel R, Deisseroth K, Stadler MB, Müller C, Lüthi A (2010) Encoding of conditioned fear in central amygdala inhibitory circuits. Nature 468:277-282. CrossRef Medline

Cui G, Jun SB, Jin X, Pham MD, Vogel SS, Lovinger DM, Costa RM (2013) Concurrent activation of striatal direct and indirect pathways during action initiation. Nature 494:238-242. CrossRef Medline

Day HE, Curran EJ, Watson SJ Jr, Akil H (1999) Distinct neurochemical populations in the rat central nucleus of the amygdala and bed nucleus of the stria terminalis: evidence for their selective activation by interleukin1beta. J Comp Neurol 413:113-128.

Driscoll JD, Shih AY, Iyengar S, Field JJ, White GA, Squier JA, Cauwenberghs G, Kleinfeld D (2011) Photon counting, censor corrections, and lifetime imaging for improved detection in two-photon microscopy. J Neurophysiol 105:3106-3113. CrossRef Medline

Duvarci S, Pare D (2014) Amygdala microcircuits controlling learned fear. Neuron 82:966-980. CrossRef Medline
Duvarci S, Popa D, Paré D (2011) Central amygdala activity during fear conditioning. J Neurosci 31:289-294. CrossRef Medline

Erlich JC, Bush DE, Ledoux JE (2012) The role of the lateral amygdala in the retrieval and maintenance of fear-memories formed by repeated probabilistic reinforcement. Front Behav Neurosci 6:16. CrossRef Medline

Fanselow M, Lester L (1988) A functional behavioristic approach to aversively motivated behavior: Predatory imminence as a determinant of the topography of defensive behavior. In: Evolution and learning (Bolles RC, Beecher MD, eds), pp 185-211. Hillsdale, NJ: Erlbaum.

Gründemann J, Lüthi A (2015) Ensemble coding in amygdala circuits for associative learning. Curr Opin Neurobiol 35:200-206. CrossRef Medline

Gunaydin LA, Grosenick L, Finkelstein JC, Kauvar IV, Fenno LE, Adhikari A, Lammel S, Mirzabekov JJ, Airan RD, Zalocusky KA, Tye KM, Anikeeva P, Malenka RC, Deisseroth K (2014) Natural neural projection dynamics underlying social behavior. Cell 157:1535-1551. CrossRef Medline

Haubensak W, Kunwar PS, Cai H, Ciocchi S, Wall NR, Ponnusamy R, Biag J, Dong HW, Deisseroth K, Callaway EM, Fanselow MS, Lüthi A, Anderson DJ (2010) Genetic dissection of an amygdala microcircuit that gates conditioned fear. Nature 468:270-276. CrossRef Medline

Herry C, Johansen JP (2014) Encoding of fear learning and memory in distributed neuronal circuits. Nat Neurosci 17:1644-1654. CrossRef Medline

Jia H, Rochefort NL, Chen X, Konnerth A (2011) In vivo two-photon imaging of sensory-evoked dendritic calcium signals in cortical neurons. Nat Protoc 6:28-35. CrossRef Medline

Johansen JP, Cain CK, Ostroff LE, LeDoux JE (2011) Molecular mechanisms of fear learning and memory. Cell 147:509-524. CrossRef Medline

Killcross S, Robbins TW, Everitt BJ (1997) Different types of fearconditioned behaviour mediated by separate nuclei within amygdala. $\mathrm{Na}-$ ture 388:377-380. CrossRef Medline

LeDoux JE, Iwata J, Cicchetti P, Reis DJ (1988) Different projections of the central amygdaloid nucleus mediate autonomic and behavioral correlates of conditioned fear. J Neurosci 8:2517-2529. Medline

Li H, Penzo MA, Taniguchi H, Kopec CD, Huang ZJ, Li B (2013) Experience-dependent modification of a central amygdala fear circuit. Nat Neurosci 16:332-339. CrossRef Medline

Madisen L, Zwingman TA, Sunkin SM, Oh SW, Zariwala HA, Gu H, Ng LL, Palmiter RD, Hawrylycz MJ, Jones AR, Lein ES, Zeng H (2010) A robust and high-throughput Cre reporting and characterization system for the whole mouse brain. Nat Neurosci 13:133-140. CrossRef Medline

Madisen L, Mao T, Koch H, Zhuo JM, Berenyi A, Fujisawa S, Hsu YW, Garcia AJ 3rd, Gu X, Zanella S, Kidney J, Gu H, Mao Y, Hooks BM, Boyden ES, Buzsáki G, Ramirez JM, Jones AR, Svoboda K, Han X, et al. (2012) A toolbox of Cre-dependent optogenetic transgenic mice for light-induced activation and silencing. Nat Neurosci 15:793-802. CrossRef Medline

McNaughton N, Corr PJ (2004) A two-dimensional neuropsychology of defense: fear/anxiety and defensive distance. Neurosci Biobehav Rev 28: 285-305. CrossRef Medline

Murray AJ, Sauer JF, Riedel G, McClure C, Ansel L, Cheyne L, Bartos M, Wisden W, Wulff P (2011) Parvalbumin-positive CA1 interneurons are required for spatial working but not for reference memory. Nat Neurosci 14:297-299. CrossRef Medline

Penzo MA, Robert V, Li B (2014) Fear conditioning potentiates synaptic transmission onto long-range projection neurons in the lateral subdivision of central amygdala. J Neurosci 34:2432-2437. CrossRef Medline

Penzo MA, Robert V, Tucciarone J, De Bundel D, Wang M, Van Aelst L, Darvas M, Parada LF, Palmiter RD, He M, Huang ZJ, Li B (2015) The paraventricular thalamus controls a central amygdala fear circuit. Nature 519:455-459. CrossRef Medline

Quirk GJ, Repa C, LeDoux JE (1995) Fear conditioning enhances shortlatency auditory responses of lateral amygdala neurons: parallel recordings in the freely behaving rat. Neuron 15:1029-1039. CrossRef Medline

Schiff W, Caviness JA, Gibson JJ (1962) Persistent fear responses in rhesus monkeys to the optical stimulus of "looming." Science 136:982-983. CrossRef Medline

Taniguchi H, He M, Wu P, Kim S, Paik R, Sugino K, Kvitsiani D, Kvitsani D, Fu Y, Lu J, Lin Y, Miyoshi G, Shima Y, Fishell G, Nelson SB, Huang ZJ (2011) A resource of Cre driver lines for genetic targeting of GABAergic neurons in cerebral cortex. Neuron 71:995-1013. CrossRef Medline

Zhang F, Wang LP, Boyden ES, Deisseroth K (2006) Channelrhodopsin-2 and optical control of excitable cells. Nat Methods 3:785-792. CrossRef Medline 